\title{
医薬品開発のためのバイオマーカー
}

\section{Biomarkers for Drug Discovery and Development}

\author{
小田吉哉 \\ Yoshiya OdA \\ エーザイ株式会社
}

現在先進諸国では国内総生産（GDP）に対する総医療 費の割合が8〜 $11 \%$ ，アメリカでは $16 \%$ でその割合がさら に増え続けている ${ }^{1)}$.したがって今後の経済成長と財政の 健全化を目指すうえで医療費を抑制することは重要な課題 であり，その施策の一つとして薬剤費の削減がある。医薬 品市場に损いてジェネリック医薬品（後発医薬品）が占め る割合はアメリカが約9割, ドイツが約8割に対して, 日 本はまだ 5 割未満なので 2 , 日本政府は 2020 年までに後発 医薬品の割合を市場の 8 割まで増やすとしている ${ }^{3)}$. よっ て新薬メーカーは主力品の特許切れまでに次の新薬を市場 に送り出したい．しかし新薬に必要な開発費は年々増加し ており, 2010年頃には一つの新薬を生み出すまでに約 10 億ドル, 今では約 15 億ドルもの開発費用が必要とされて いる ${ }^{4)}$ 。そのため製薬会社は合併買収によって新薬開発に 必要な資金を集めたり, 優先度が低い事業領域を切り離し て資源の集中を図ったりして, 新薬の開発を急いでいる. 患者側から見れば, 現在十分な治療効果が得られる薬剤は 安いほうが経済的に助かるが, 既存薬がない, あるいは既 存薬では効果が不十分な疾患では, 頼れる存在は後発医薬 品メーカーではなく, 新薬メーカーである。したがって新 薬メーカーの生産性, つまり成功確率の向上が急務であ る.

M. Ringel らは過去 10 年間の 842 件の新薬プロジェクト （205件が承認，637件が失敗）についてデータを精査した 結果, 研究開発の予算規模や会社の所在地, 疾患領域や市 場の大きさ，薬剤の標的や種類などは成功確率と相関がな く, 最も高い相関を示したのはプロジェクトを早期に終結
させる決断であった ${ }^{5}$. 医薬品開発において開発ステージ が先に進むほど費用が増大し, 特に臨床第三相試験に至っ ては莫大な費用が必要となる。しかし臨床試験の成功確率 は僅か $10 \%$ あ゙る ${ }^{6)}$. そのために成功確度が高いプロジェ クトのみを臨床導入すること, 特に費用が高い臨床第三相 試験の手前での判断が重要となる。ファイザー社は過去 44 件の臨床第二相試験の自社事例から 3 本の矢を提唱して いる7). それは1）exposure at the target site of action, 2) binding to the pharmacological target, 3) expression of pharmacologyである. 臨床第二相試験までに, この三つのう ち一つでも確認できなければ，そのプロジェクトを臨床第 三相試験に進めるべきではないとしている（表1）。アス トラゼネカ社でも化合物選択から臨床第二相試験まで自社 の過去 142 件のプロジェクトを吟味した結果, プロジェク トの成功を左右する五つの重要な因子（Right target, Right tissue, Right safety, Right patients, Right commercial potential）を見いだすことができた，さらに適切な意思決定を 促進する文化（Right culture）も大切であると強調してい $る^{8)}$. Peck らは正しい意思決定を阻害する要因として, プ ロジェクトの数が十分でないことと, バイオマーカーアッ セイの信頼性が足りないことを強調している ${ }^{9)}($ 表2). イーライリリー社ではThe quick-win, fast-fail モデルとして Chorusを立ち上げ実践している。ここでも鍵となるのが バイオマーカーの活用である ${ }^{10)}$.

さて一般的なバイオマーカーとは「通常の生物学的過 程, 病理学的過程, もしくは治療的介入に対する薬理学的 応答の指標として, 客観的に測定され評価される特性」と

表 1. 後期臨床試験に進む意思決定をするバイオマーカー

\footnotetext{
Target engagement: proof-of-mechanism (POM)*

Target exposure: pharmacodynamic (PD) marker ${ }^{\#}$

Target modulation: POM/PD marker**

*POMを達成しない場合

*POMを達成したが, 薬効がない場合

*PDマーカーがない場合
}

薬剤が標的分子に直接作用したか?

薬剂が標的に適切な濃度まで達したか?

薬剤が標的の機能を変化させたか?

プロジェクトの中止

バックアップも含めプロジェクトの中止

適切な投与量, 投与計画が設定できないため, 臨床試験が肥大する危険がある

連絡先：Yoshiya_Oda@eisai.com 
表2. 医薬品プロジェクトを成功させるための要因

\begin{tabular}{|c|c|}
\hline Right target & 標的と疾患を結ぶバイオロジーを十分理解できているか? \\
\hline Right tissue & 薬剂が標的に適切な濃度で作用し機能を変えたか？ \\
\hline Right safety & 安全マージンは？ オフターゲットは？ 薬剤代謝物は？ \\
\hline Right patients & 薬剂が効きやすい（副作用を起こしやすい）集団は？ \\
\hline Right commercial potential & 標準治療との優位性は？ 市場に受け入れられるか？ \\
\hline Right assay & バイオマーカー測定法の特異性, 再現性など信頼性は？ \\
\hline Right culture & 意思決定, 特に早期に断念することができる環境か？ \\
\hline
\end{tabular}

定義されており，広義には日常診療で用いられるバイタル サインや, 生化学検査, 血液検査, 腫瘍マーカーなどの各 種臨床検査值や画像診断データなどが含まれるとしてお $り^{11)}, \mathrm{FDA}$ (米国食品医薬品局) はバイオマーカーの位 置づけを，「正常なプロセスや病的プロセス，あるいは治 療に対する薬理学的な反応の指標として客観的に測定・評 価される項目」としている ${ }^{12)}$ 。ここでファイザー社が提 唱する3本の矢のうち2）と3）を別の言葉に置き換えると Target engagement $と$ Target modulation となりこれは proof-of-mechanism (POM) のことであり,すなわち薬 剂候補化合物が目的の標的に結合し, 期待どおりの作用を 示したことをバイオマーカーで確認できれば, POMを達 成したと考えられる (表1).つまり前臨床試験でPOMを 達成できれば臨床導入し, 前期臨床試験で POMを確認で きれば後期臨床試験に進める判断指標となる。もし POM 確認試験をせず，化合物が薬剤効果を示さなかった場合， それは標的が間違っていたのか, 化合物が標的に作用しな かったのか不明となり, 教訓を次に活かすことができな い。逆に臨床でPOMを達成したにもかかわらず，薬剤に 効果がなければ，その疾患においては，その標的分子が重 要でないことを意味している。したがってバックアッププ ロジェクトも必要ない. 3 本の矢のうち残る1本は pharmacodynamic marker (PD marker : 薬力学マーカー) であ り, 薬剤候補化合物が標的部位で必要な濃度に到達したか について, 薬剤候補化合物自身を測るのではなく PDマー カーの増減でもって判断指標とする（表 1$)$. なお PDマー カーの一つとして, またPOMの一つでもあるPET（ポジ トロン断層法 : positron emission tomography) イメージン グで使われる受容体占有率（Receptor occupancy）は標的 に対して何\%薬剤候補化合物が占めているか測定すること で適切な投与量を設定する。ヒトでのPOM確認の難しさ は病変部位を容易に手に入れることができないことであ り，血液など手に入る試料では化合物の標的が存在しない ことのほうが多い，その点, PETイメージングによる受容 体占有率試験ならヒトでの実施が比較的容易であるが, 新 規標的の場合PETプローブの特異性を確認することが非 常に重要である.

アストラゼネカ社が提唱する Right targetはプロジェク トの最初に徹底的に検討すべき項目であるが, ヒトで POM 達成し, かつ薬剤の効果も確認できて初めて Right targetであると言える. Right tissueについては, 明確に Target engagementを確認する必要があると述べられてお り, PDマーカーをきちんと測定することがRight tissueに
つながるとしている．Right patientは薬剤が効く患者を見 いだすことが重要で，そのためには特定の薬剤による効果 を予測する予測マーカー（predictive marker）を設定する 必要がある。患者を見分けるという意味では層別化マー カー（stratification marker）と呼ぶこともある。つまり薬 剂の標的に関連した分子を（多く）発現している，もしく は発現していない患者を選別することになる．アストラゼ ネカ社では後期臨床第二相試験の際に, 層別化マーカーが あった場合は成功確率が $90 \%$ だったのに対して，なかっ

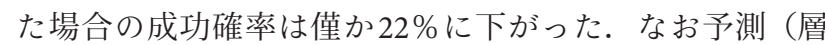
別化）マーカーを用いて患者を選んで臨床試験を行う場 合, 層別化のための診断薬が必要になる。そして診断薬の 承認のためには薬剤と同様に前向きの試験が必要になるの で, 薬剤と同時に診断薬の臨床開発の申請承認も必要にな る(コンパニオン診断薬). 現在のコンパニオン診断薬は 薬剤と診断薬の 1 対 1 の関係である（それぞれの表示に, 対応する特定の薬剤あるいは診断薬が記載される）が，今 後もこの関係性が維持されるか, 規制当局の動きをしっか り見ておく必要がある. Right safetyでは前臨床で安全性 に懸念がある薬剤候補を臨床試験前に止めるだけではな く, 必要に応じて安全性マーカー（safety marker）を設定 することで副作用の回避, 低減に役立てる（表2）。 また 臨床第二相試験を始める際に, 薬剤の効果をモニタリング するマーカー（efficacy/monitoring marker）があった場

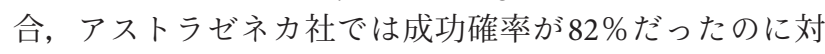
して，なかった場合は成功確率が $29 \%$ なっった。薬剤の 効果についてバイオマーカーにより長期間追跡できれば, 治療から治癒に向かう場合と薬剤が効かなくなる（薬剤耐 性になる）時期を把握できるかもしれない。このような薬 効マーカーと疾患のメカニズムを詳細に調べることができ れば, 次の創薬プロジェクトにつながる.

ところで予測マーカー（predictive marker）とよく間違 われるマーカーとして予後マーカー（prognostic marker） がある ${ }^{13)}$, 14). 予後マーカーは特定の治療によらない疾病 の経過を予測するバイオマーカーのことであり，特定の薬 剂の効果を予測するマーカーではないため, 創薬に必須と は言えないが, 自分らが測定しているバイオマーカーは, 予測なのか予後なのか注意して見極める必要がある。また 予後マーカーは診断マーカー（diagnostic marker）とも関 係している．診断マーカーは「今」を判断するバイオマー カーであり, 予後マーカーは「今後」を予想するバイオ マーカーである。診断マーカーには主に二つあって, 一つ は病気の有無を判断し, 疾患を特定する診断マーカーと, 
表3. 意思決定以外にも医薬品開発に有用なバイオマーカー

\begin{tabular}{|c|c|}
\hline $\begin{array}{l}\text { Predictive biomarker } \quad \text { 予測マーカー } \\
\text { (Stratification marker 層別化マーカー) }\end{array}$ & 特定の薬剂が効きやすい集団を見分けるバイオマーカー, コンパニオン診断薬候補 \\
\hline Prognostic biomarker 予後マーカー & 特定の治療に関係なく疾患の進行や回復を予想するバイオマーカー \\
\hline Efficacy/monitoring biomarker 薬効マーカー & $\begin{array}{l}\text { 薬剂の効き具合, 治療効果を診るマーカー, 長期間モニタリングすることで薬剤耐 } \\
\text { 性の原因解明のヒントにもなりる }\end{array}$ \\
\hline $\begin{array}{l}\text { Diagnostic biomarker } \\
\text { 診断マーカー（二つのタイプがある） }\end{array}$ & $\begin{array}{l}\text { 疾患の有無や疾患の種類を特定する診断マーカーと, 疾患の重症度や進行度を判定 } \\
\text { する診断マーカーの } 2 \text { 種類がある }\end{array}$ \\
\hline Companion diagnostics コンパニオン診断薬 & 特定の薬剤が効きやすい集団を見分けるための診断薬で, 薬剤と一緒に開発し申請 \\
\hline $\begin{array}{l}\text { Surrogate endpoint marker } \\
\quad \text { サロゲートエンドポイントマーカー }\end{array}$ & $\begin{array}{l}\text { 真のエンドポイントとの科学的な関係が証明されているマーカー. 臨床試験で用い } \\
\text { る場合は, 許認可当局との事前合意が必要 }\end{array}$ \\
\hline
\end{tabular}

表4. 医薬品開発の生産性を高める二つの要因

成功確度の低いプロジェクトを止める

プロジェクトの成功確度を高める
薬剤候補化合物を確定した後の手段

薬剂候補化合物を確定する前の手段，あるいは薬剤が効くであろう患者群を特定できる マーカーがあり, かつ先行品や優れた標準治療法がない領域を選ぶ場合
もう一つは疾患の状態, 例えば進行度や重症度を判断する 診断マーカーであり, 定量的で, 病気の進行具合を精度良 く測定できるなら，これは薬剤の治療効果を見るモ二タリ ングマーカーとしても使えるので, 薬㓮開発上意識してお くバイオマーカーである(表3).

医薬品開発におけるバイオマーカーとして忘れてはいけ ないものとしてサロゲートエンドポイントマーカー（代替 エンドポイントマーカー： surrogate endpoint marker）が ある ${ }^{15), 16)}$ 。これは臨床試験の真のエンドポイントを代替 するマーカーで, 真のエンドポイントとの科学的な関係が 証明されているマーカーのことである. 例えば真のエンド ポイントが「心疾患による死」なら, サロゲートマーカー は「コレステロール值」や「血圧」である，通常臨床試験 の期間内で真のエンドポイントを評価することは難しい場 合は，サロゲートエンドポイントが採用される，ただしあ らかじめサロゲートマーカーについて臨床での有用性が確 認されていなければならないことと, FDA や厚労省との 事前相談が必須となる。なお臨床でバイオマーカーの有用 性を再現するのは容易ではない。例えば乳がんにおける ER/PR, HER2 や大腸がんでの G13D変異以外の K-ras変異, 非小細胞肺がんにおけるEGFR変異とEML4-ALK融合遺 伝子については臨床で使うのに有用であり推薦できるとさ れているが，これまで有用と思われてきた乳がんでの Oncotype DX や大腸がんのEGFR遺伝子の発現, 非小細胞肺 がんにおけるK-ras変異などは現時点では推奨できるもの ではないとされている ${ }^{17)}$.

これまで述べてきた医薬品開発におけるバイオマーカー は, 臨床試験あるいは臨床試験開始時におけるバイオマー カーの役割であり, 成功確率を上げるというよりは成功の 見込みが低いプロジェクトを終結させる判断に使うバイオ マーカーである（表4）。薬剤候補化合物を決めてしまっ たなら，その後に成功確率を上げる方策は，その薬剤に適 した患者のみに焦点を当てた臨床試験を実施すること，つ
まり予測（層別化）マーカーを設定することである（表 3). 成功確率を高めるためには薬剤候補を決める前に薬剤 の特異性を十分に評価して, 最も優れた化合物を選びた い. 例えば標的が酵素である場合，その基質と産物を確認 することが一般的である. しかし複数の酵素が同じ基質を 標的としている場合もあるので, 特定の基質一産物の変化 を調べることが必ずしも特異性を評価したと言い切れな い. 放射性リガンド置換アッセイは受容体に対して化合物 がどの程度結合したか調べるのに使われるが，その結果に ついては，リガンドの特異性に大きく依存する。したがっ て新規の標的の場合，そのような信頼できるリガンドを手 に入れることが最初の難関となる。リン酸化キナーゼ阻害 剂に関しては，インビトロで多数のキナーゼをパネル化し たキナーゼ阻害プロファイルが行われている．しかしある 種のキナーゼは生きた細胞内でしか活性を示さないことも あるため, 真に特異性を評価したとは言い難い 18) 20).

前臨床，特に化合物選択の前では，薬剤候補化合物に対 する評価を網羅的に実施して，可能な限り特異性が高い化 合物を選ぶようにしたい（表5)。例えばリン酸化プロテ オミクスとケミカルプロテオミクスを合わせた Kinobeads による解析やActivity based protein profiling を用いた分析 では, 組換えキナーゼアッセイとは異なる結果が得られて おり，生きた細胞で特異性を確認する大切さが認識されつ つある．基質と酵素が異なる組織で産生されることもある ので単純な細胞系のみでの確認は危険が伴うし, 動物・ヒ トレベルでは，一つの基質が複数の酵素の影響を受けるこ ともあるので, やはり網羅的に検討することが重要であ る.またリガンドと標的タンパク質の相互作用解析にはケ ミカルプロテオミクスや免疫沈降一質量分析解析が有用で あり，さらにLC/MSによって複数のリガンドを同時に測 定することも行われていて，臨床試験に比べて圧倒的に費 用が安い前臨床試験で, 可能な限り多くのデータを出して 薬剤候補化合物の評価を行っておくことが結果的に費用の 


\section{Y. ODA}

表5. 薬剤候補化合物に対して質量分析を駆使して詳細に検討すべきこと

\begin{tabular}{|c|c|}
\hline 酵素阻害剂の特異性を評価する場合 & $\begin{array}{l}\text { 複数の酵素が同じ基質を標的としている場合もあるので, 基質と産物の } \\
\text { 変化について網羅的に検討 }\end{array}$ \\
\hline $\begin{array}{l}\text { 薬剂の特異性評価として放射性・単光リガンド置換アッ } \\
\text { セイを使う場合 }\end{array}$ & 使用するリガンドの特異性について要確認 \\
\hline $\begin{array}{l}\text { 薬剂のPOM P PDマーカーとしてPETイメージングに } \\
\text { よる受容体占有率を使う場合 }\end{array}$ & PETリガンドの特異性について要確認 \\
\hline リン酸化キナーゼ阻害剤の特異性を評価する場合 & $\begin{array}{l}\text { インビトロのパネル化したアッセイではなく生きた細胞を使っての網羅 } \\
\text { 的な検討 }\end{array}$ \\
\hline $\begin{array}{l}\text { 細胞レベル，個体レベルにおける薬率候補化合物の特異 } \\
\text { 性について評価する場合 }\end{array}$ & クロス反応が予想される標的以外にも off targetsがないか網羅的に検討 \\
\hline 薬剤候補化合物の真の標的を探索する場合 & $\begin{array}{l}\text { 化合物が作用する標的や標的周辺分子探索, 標的に対する化合物の結合 } \\
\text { 部位の特定 }\end{array}$ \\
\hline $\begin{array}{l}\text { 薬剂候補化合物の細胞内濃度, 組織内分布, 体内分布を } \\
\text { 検討する場合 }\end{array}$ & $\begin{array}{l}\text { 薬剂候補化合物を（放射性元素や蛍光）標識せずに, 薬剤代謝物も含め } \\
\text { て検討 }\end{array}$ \\
\hline トランスレーショナル研究をする場合 & 表 1,3 のバイオマーカーについて臨床で入手可能な試料での測定を検討 \\
\hline バイオマーカーを分析する場合 & 測定方法の確からしさ（例えばイムノアッセイの特異性）について検討 \\
\hline
\end{tabular}

表 6. 標的分子と疾患との関係について質量分析を駆使して検討すべきこと

\begin{tabular}{ll} 
標的分子の機能・役割を知る & $\begin{array}{l}\text { 標的分子周辺と疾患部位, 疾患部位と正常部位の相違について網羅 } \\
\text { 的に検討 }\end{array}$ \\
標的分子の分布挙動について知る & 細胞内分布, 組織内分布, 体内分布を検討 \\
標的分子のアイソフォームや翻訳後修飾の有無について知る & $\begin{array}{l}\text { 細胞レベル, 動物レベルだけでなくヒトレベルや, 局在する場所で } \\
\text { の違いも検討 }\end{array}$ \\
標的分子に対する内在性リガンド, あるいは受容体，基質， & 標的分子に対応する分子の特定とそれらの疾患時における変化につ \\
複合体について知る & いて検討 \\
標的分子の疾患時と正常時の寿命を知る & 標的分子の生体内での半減期などを検討 \\
標的分子の疾患時と正常時の違いを知る & 標的分子の生体内での発現や修飾を検討 \\
標的分子に対する塩基配列変化の影響について知る & 塩基配列の変化による標的分子の機能変化や薬剂候補化合物の反応 \\
& 性の違いを検討 \\
\hline
\end{tabular}

削減，つまり生産性の向上につながる ${ }^{21) ~ 25) . ~}$

標的分子の確からしさについて，競合他社が同じ標的に ついて検討しているなら，その情報は役に立つが，他社に 先駆けて開発している場合は，その標的の妥当性が不確か な場合も多い。例えばがん領域では，ゲノム解析の大幅な 進展によって，標的候補となるがん遺伝子やがん抑制遺伝 子が次々に見つかってきている。さらには腫瘍内での多様 性の存在や分子標的薬に対する遺伝子変化を伴う抵抗性の 獲得なども明らかになってきた。しかし細胞をがん化に導 く遺伝子変化（Driver mutation/alteration）の頻度は思っ たほど多くはなく, 遺伝子変化の多くは細胞の表現型を変 えるには至らない，あるいは機能変化がないと思われてい る変化 (Passenger mutation/alteration) である26),27).そし て一つの遺伝子の変化だけでは説明できないこともあり, 例えば疾患部位に対する生体側の反応なども調べる必要が ある.つまり標的分子とその周辺を網羅的に調べることが 標的分子の確からしさにつながる. 最近では標的バリデー ションにケミカルプロテオミクスが有力であることが再認 識されつつある. 例えばタンパク質ータンパク質相互作用
を低分子化合物で阻害することは困難とされてきたが，最 近，低分子化合物が BETファミリーに作用してタンパク 質ータンパク質相互作用を阻害することが確認され，LC/ MSによってブロモドメインが阻害剤の標的であることも 明らかになった ${ }^{28), 29)}$ 。 また標的タンパク質の半減期が長 ければ，標的と共有結合を作る化合物も有望になるなど， 化合物の設計に影響を与えうる ${ }^{30)}$ 。このように標的を遺 伝子レベルだけでなくタンパク質レベルで評価することも 重要であり,さらには標的の下流に位置する分子群を精査 する必要もある（表6）.

生命科学の大幅な進歩によって症状や解剖学, 組織学に よって疾患を分類する時代から遺伝子など分子レベルで分 類する時代になってきている. それに伴って，これまでの One-size-fits all clinical trialという考え方からPrecision Medicineの時代となり，そのためには仮説検証型が重要 で，そこではバイオマーカーに基づいた臨床試験が必須で ある．創薬におけるバイオマーカーとは，薬剤の作用メカ ニズムに基づいた明確な理由づけができるバイオマーカー のことであり，そのバイオマーカーは検出かつ定量でき， 
たとえ複数のバイオマーカーを同時に測定する場合であっ ても, 測定データの質を確保することが求められている. また新規バイオマーカーには分析バリデーションに加えて 臨床バリデーション, 臨床での有用性, そして既存のバイ オマーカーに対する優位性によって，初めて創薬で「使え る」バイオマーカーとなる。このようにバイオマーカーは 医薬品開発の色々な場面で必須項目になっている.

\section{文献}

1) http://kff.org/health-costs/issue-brief/snapshots-health-carespending-in-the-united-states-selected-oecd-countries/

2) http://apps.who.int/prequal/trainingresources/pq_pres/meetings_ generics_22May2013/Richard_Laing.pdf

3) https://www.kantei.go.jp/jp/singi/gskaigi/working/dai6/siryou3. pdf

4) J. W. Scannell et al., Nat. Rev. Drug Discov., 11, 191 (2012).

5) M. Ringel et al., Nat. Rev. Drug Discov., 12, 901 (2013).

6) M. Hay et al., Nat. Biotechnol., 32, 40 (2014).

7) P. Morgan et al., Drug Discov. Today, 17, 419 (2012).

8) D. Cook et al., Nat. Rev. Drug Discov., 13, 419 (2014).

9) R. W. Peck et al., Nat. Rev. Drug Discov., 14, 663 (2015).

10) P. K. Owens et al., Nat. Rev. Drug Discov., 14, 17 (2015).

11) Biomarkers Definitions Working Group, Clin. Pharmacol.
Ther., 69, 89 (2001).

12) http://www.pharm.or.jp/dictionary/wiki.cgi?\%E3\% $83 \% 90 \%$ E3\% $82 \%$ A 4\%E3 \% 82\%AA \% E3\% 83\%9E \% E3\% 83\%BC\% $\mathrm{E} 3 \% 82 \% \mathrm{AB} \% \mathrm{E} 3 \% 83 \% \mathrm{BC}$

13) K. P. Pritzker, Expert Rev. Mol. Diagn., 15, 971 (2015).

14） K. V. Ballman, J. Clin. Oncol., 33, 3968 (2015).

15) J. K. Aronson, Br. J. Clin. Pharmacol., 59, 491 (2005).

16) http://www.fda.gov/downloads/NewsEvents/Newsroom/FactSheets/UCM455106.pdf

17) C. Chung and M. J. Christianson, Oncol. Pharm. Pract., 20, 11 (2014).

18) G. M. Simon et al., Nat. Chem. Biol., 9, 200 (2013).

19) M. E. Bunnage et al., Nat. Chem. Biol., 11, 368 (2015).

20) T. B. Durham and M. J. Blanco, Bioorg. Med. Chem. Lett., 25, 998 (2015).

21) C. P. Paweletz et al., PLoS ONE, 6, e26459 (2011).

22) R. E. Moellering and B. F. Cravatt, Chem. Biol., 19, 11 (2012).

23) M. Bantscheff and G. Drewes, Bioorg. Med. Chem., 20, 1973 (2012).

24) M. E. Bunnage et al., Nat. Chem. Biol., 9, 195 (2013).

25） E. W. Tate et al., Curr. Opin. Chem. Biol., 24, 48 (2015).

26) B. Vogelstein et al., Science, 339, 1546 (2013).

27) J. Zhang et al., Brief Bioinform., 15, 244 (2014).

28) P. Filippakopoulos et al., Nature, 468, 1067 (2010).

29) P. V. Fish et al., J. Med. Chem., 55, 9831 (2012).

30) B. R. Lanning et al., Nat. Chem. Biol., 10, 760 (2014). 